\title{
Ultrasonografia în România anului 2012
}

Ultrasonografia, într-o evoluție cu adevărat explozivă în ultimii ani atât în domeniile metodologic şi tehnologic, cât şi în privința dedicațiilor clinice, dintre cele mai specializate şi adaptate, ocupă, fără îndoială, o poziție de prim rang între preocupările medicale româneşti ale acestui an.

Congresul European de Ultrasonografie Euroson, în organizarea Federației Europene a Societăților de Ultrasonografie în Medicină şi Biologie (EFSUMB), organizat la Madrid, în Palatul Municipal al Congreselor, în perioada 22-24 aprilie 2012, (http://www.euroson2012.com), amplă manifestare, la care sunt aşteptați în acest an peste 1000 de participanți, va atrage şi participarea specialiştilor români. La secțiunea Young Investigator Societatea Română de Ultrasonografie în Medicină şi Biologie (SRUMB) este reprezentată de către Dr. Mihai Socaciu cu lucrarea: „Perfusion Quantification in Treated Hepatocellular Carcinoma using CEUS“.

În perioada 31 mai-2 iunie 2012, oraşul Cluj-Napoca va deveni "capitala ultrasonografiei” în România. A XV - a Conferință Națională a Societății Române de Ultrasonografie în Medicină și Biologie (www. medevents.ro/conferintasrumb2012), manifestare devenită tradițională, esența manifestării fiind constituită de către caracterul său multidisciplinar, va beneficia de un număr important de oaspeți din străinătate şi de la alte societăți profesionale. Conferința va fi precedată de un număr de 10 cursuri preconferință, dintre care 4 cursuri Endorsed, sub egida EFSUMB. Temele cursurilor sunt extrem de diversificate: urgențe, pacientul în stare critică, gastroenterologie şi hepatologie, patologia vasculară, patologia mamară şi a glandelor endocrine, ultrasonografia intervențională, utilitatea şi aplicațiile în obstetrică şi ginecologie, nefro-urologie, pediatrie, medicina veterinară, precum şi ultrasonografia pentru studenții la medicină. Conferința va cuprinde apoi un număr important de mese rotunde şi simpozioane în care vor fi prezentate experiența şi ultimele realizări ale specialiştilor români, precum şi sesiunile tradiționale de prezentări originale, orale, poster şi video. Conferințele, de asemenea tradiționale, „Gh. Badea” şi „Gh. Jovin” vor fi susținute şi în acest an de personalități internaționale importante invitate.

Pentru prima dată va fi organizat un simpozion cuprinzând educația în medicină, pe toate palierele, folosind ultrasonografia.

La Craiova începând cu luna martie 2012 va fi organizat un curs de ecografie generală, cu durata de trei luni, adresat în primă intenție studenților la medicină şi medicilor rezidenți, precum şi specialiştilor care vor dori să se pregătească pentru practica ultrasonografiei cu atestat de studii complementare.

Acest curs este dezvoltat în cadrul proiectului E-EDUMED LLP/LdV/TOI/ RO/2010/006 intitulat Centru Educațional e-learning în Medicină (http://www.eedumed.ro).

Proiectul e-EDUMED dezvoltă trei module pentru ecografie, care se înscriu în rândul programelor de EMCD prin internet, online, fiind interactive atât prin consultanța cu tutori de program acreditați, cu asigurarea unei testări finale securizate, tot prin acces on-line personalizat, cât şi prin suportul informațional oferit, cu link-uri şi portaluri specifice. Pentru fiecare modul se vor dezvolta pachete conținând 0

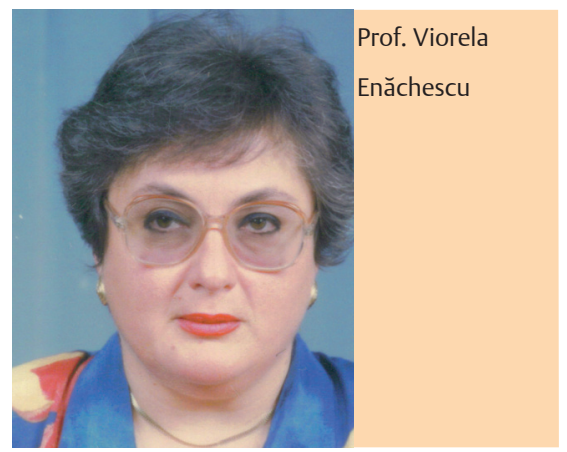

secțiune pentru bazele anatomice, semne clinice şi paraclinice, imagini ecografice şi filme, un sistem de evaluare şi autoapreciere al rezultatelor. Sistemul va furniza un feedback prin identificarea diagnosticului corect. O secțiune specială va permite chatting, sharing-ul conținutului şi tutoring de către furnizorul cursului.

Platforma e-learning va include: cursuri on line asincrone - PPT şi note de curs, lecții multimedia, cursuri on-line sincrone - cursuri implementate în cadrul clasei virtuale e EDUMED, chestionare pentru autoevaluarea competențelor.

Centrul de Formare în Ultrasonografie Cluj va organiza în data de 5 mai, în Centrul Universitar Iaşi un curs de ecografie cu produşi de contrast şi elastografie ARFI, abordând două domenii într-o dezvoltare efervescentă în ultimii ani.

Centrul de Formare în Ultrasonografie Timișoara, World Federation for Ultrasound in Medicine and Biology Center of Excellence organizează la Timișoara Workshopul anual în perioada 21-22 septembrie 2012, cu tema „Up-to-date in abdominal ultrasound“. Manifestarea va fi precedată în perioada 20-21 septembrie 2012 de un curs EFSUMB Endorsed - Ultrasound Elastography In Gastroenterology And Hepatology (e-mail: centr.form. us.tm@gmail.com).

Prof. Viorela Enăchescu

Secretar General al SRUMB 